\title{
AUTHENTICITY OF NARRATIVE TEXT MODELS USED IN JUNIOR HIGH SCHOOL TEXTBOOKS
}

\author{
Agung Hariyadi \\ SMPN 1 Poncowarno, Kebumen, Central-Java, a9un9hariyadi@gmail.com
}

\begin{abstract}
This present research focuses on two purposes: they are to find out the application of Vladimir Propp's theory on narrative text models used in Junior High School Textbooks and the authenticity of narrative text models used in Junior high school textbooks. To answer the first research question, the theory is used to analyze the data through document analysis and the second research question answered by comparing the analyses of the text models of JHS textbooks and the authentic texts. The data were four narrative text models taken from four junior high school textbooks that contain narrative texts and the storybook as an example of authentic text. The result showed that the theory was generally applicated on narrative text models used in Junior High School and all of them are belong to not authentic. Three of them are the simplification of the authentic texts and the other is created text. This was caused by context of used (classroom), cultural context and students level of knowledge.
\end{abstract}

Keywords: Authenticity, Narrative text, Vladimir Propp's theory of narrative,

Countries all over the world are trying hard through different ways to improve their educational programs. In an effort to achieve this purpose, they continuously introduce and evaluate their educational curriculum, syllabuses, and textbooks. The evaluation process covers different fields of the curriculum; mostly the content represented by the textbook. Although the textbook is not the only tool for the teaching and learning process, it is of a significant impact for achieving the language learning objectives. It gives more emphasis on the use and utility of the textbook to compensate the loss of authentic materials since teachers find the difficulties in developing their own classroom materials, have limited time and lie under external pressure that limit their ability.

In Indonesia English is taugh as foreign language, in order to reach the competence, the authentic material is very needed. The use of authentic material in textbooks is necessary because it has many advantages. Richards (2001, pp. 252-253) summarize the main advantages of using authentic materials in the classroom in the following points:

1. Having a positive effect on students motivation;

2. Giving authentic cultural information;

3. Exposing students to real language;

4. Relating more closely to students' need;

5. Suporting a more creative approach to teaching.

Authentic texts can be motivating because they are proof that the language is used for real life purposes by real people (Nuttall, 1996, p. 172). In shorts, the authentic material bring learners close to the target of language culture, making learning more enjoyable and motivating. The interest of the students to a text will lead them to success in learning the target language. On the other hand, If the textbooks contain a non-authentic materials it will far from the target language culture, less motivating and doesn't support the succeed in learning the target language.

Nowadays, our government have implemented two educational curriculums, 2006 and 2013. Dealing with the curriculum 2013 especially for VII and VIII grade, Teacher books and student books have been prepared by Government in accordance with Permendikbud No.71 year 2013 on Textbooks and Teacher Handbook, for IX grade is still using the curriculum 2006 (KTSP). Both in curriculum 2013 and 2006, there are five kinds of text that should be taught to the students of Junior High school students, they are descriptive, procedure, recount, narrative and report text. 
Narrative text is chosen in this research for some reasons. First, As one of text genre that should be taught in Junior High School, narrative has an important role in teaching and learning English. Butt, Fahey, Spinks, and Yallop (2000) points out that narrative is a special kind of story that is valued very highly in English. Second, As a text type which has the potential to make students learn the moral values, Bouchard (2002) argue that a narrative may contribute to students' knowledge about moral values and character which works with their lives. Rosyidah (2012) states that English Language Teaching especially in teaching narrative can serve as means of character values integration.

Vladimir Propp in his book entitled The Morphology of the Folktale was able to break the plot structure of narrative based on the result of his research on the Russian folktales. Propp (1968) identified eight types of characters and thirty one functions that are suitable to analyze the structure of folktales. And stated that functions is the most stable structure of the folktales. Vladimir Propp's theory of narrative is chosen in this research because beside it is important part in narrative, helped other studies in related areas and the result of the analysis of the characters and functions will be used to analyze the extent of the authenticity of the text.

Dealing with the authenticity of the English textbook, there are many researchers who have analyzed it, they are; Kusuma (2013) doing research on the authenticity of Conversation transcripts used in Junior High school BSE Textbooks and found that many conversation transcripts are loss of authenticity. Then, Ali (2010) found that no authentic reading texts appear in grade 9th English textbooks in Palestine.

Concerning the problem above, the writer is interested in doing a research in analyzing the application of Vladimir Propp's theory on narrative text models used in Junior High School textbooks and the narrative text model used in English speaking country and comparing the result of the analysis in order to know how the authenticity of them. Based on the background of the study above, the formulation of the research questions are; 1). How does the application of Vladimir Propp's theory on the narrative text models used in Junior High School textbooks 2). How does the authenticity of narrative text models used in Junior High School textbooks resemble the narrative text models used in English speaking country?

\section{English Language Teaching (ELT) Textbooks}

English language teaching (ELT) textbooks play a central role in teaching learning process in a classroom. They are the primary agents of conveying the knowledge to the learners. Hutchinson and Torres (1994) argues that textbooks has a very important and positive part to play in teaching and learning of English. They believe that textbooks provide a necessary input to classroom lesson through different activities, reading and explanations.

Cunningsworth (1995) defines textbook as a resource in presenting the material, a source for learners to practice and do the activities. Textbooks also provide the learner reference source on grammar, vocabulary and pronunciation. Textbooks also serve as a syllabus and self-study source for learners. They also serve as a guide for a beginner teachers to gain a confidence. Thus, it can be conclude that textbooks provide material for teachers and learners.

Richards (2001, pp. 252-253) states that textbooks provide structures and syllabus, the program may not impact without textbooks. No one can deny the advantages of these textbooks. textbook has many advantages. The advantages are: 1). Providing structure and syllabus for a program; 2). Helping standardized instruction; 3) Maintaining quality; 4). Providing a variety of learner resources; 5). Being efficient; 6). Providing effective language models and input; 7). Training teachers; and 8). Being visually appealing. On the other hand, textbook also has many disadvantages, those are: 1). It may provide inauthentic material; 2). It may not reflect students needs; 3). It is expensive; 4). It may provide distort content; and 5). It can deskill teacher.

According to McDonough, Shaw, and Masuhara (2013, p. 52) No textbooks or set of materials are likely to be perfect, teachers get limited choice, under considerable professional and financial pressure to select coursebook for ELT may become a typical situation on the reason for evaluating textbooks. For some teachers, the selection of good textbooks can be valuable, 
particularly in context where the assimilation of stimulating, authentic materials can be difficult to organize.

\section{Authentic Material and Authenticity Authentic Material}

One of the most challenging tasks constantly facing language teachers is how to capture the interest and stimulate the imagination of their students so that they will be more motivated to learn. Textbooks as a media in teaching learning process which used by the teacher should provide the original material to support the teacher in stimulate and motivating their students.

There are different definition of authentic material among literatures. Morrow (1977) defines authentic text as the language produced by a real speaker or writer for a real audience which is expected to express a real message. Then Rogers and Medley (1988) move further and look at the terms authenticity and authentic as used for describing oral and written language samples that are the reflection of language forms which are used naturally and appropriately based on the cultural and situational context. Nunan (1989) and Jordan (1997) concentrate on the issue of the purpose of the text and state that authentic is any material which has not been specifically produced for the purpose of language teaching. For Harmer (1991, p. 185) also states that "authentic materials are the texts designed for the native speakers" which are real and not initially designed for language learners. Lee (1995) considers authenticity in texts which are not produced for teaching purposes but for a real communicative purpose. By this he means that the writer of a text intends to convey a message to the reader.

The use of authentic text in language learning is suported by many researchers. They regard the use of this type of materials are useful means to motivate learners, arouse their interest and expose them to real language they will face in the real world. Rogers and Medley (1988) explained that, authentic materials can meet the learners' need and interests, in addition close them more and more to real communication. Brown (2001) states that by using authentic materials and realworld tasks in language classrooms, students can find a connection between the content of the class and real life situation. Mishan (2005, p. 41) implies that authentic texts provide the best source of rich and varied comprehensible input for language learners, impacts on affective factors essential to learning, such as motivation, empathy and emotional involvement and stimulate whole brain processing which can result in more durable meaning. In addition Hyland (2003, p. 94) states that one of the most important advantages of using authentic material, is that it increase learners' motivation and reflects positively on their leaning process.

Nunan (1999) defines authentic text as spoken or written language data that has been produced in the course of genuine communication, and not specifically written for purpose of language teaching. But, He encurages His students to bring into the classroom their own samples of authentic language data from real-word context outside of the classroom such as the use of magazine stories, book stories, e.t.c. from the real world in situations for teaching speaking, listening, reading or writing.

Larimer and Schleicher (1999) stated that authentic texts in the context of language classroom, include oral and written text that occur naturally in the target language environment and that have not been created or edited expressly for language learners. In teaching Narrative, the authentic text can be magazine stories or book stories. Through these authentic texts, the students may adapt the sentence structure as the aim of reaching natural language in real life situation.

Dealing with the example of authentic material, In this research, the researcher used story book as a sample of authentic material to compare with narrative text models used in Junior High School textbooks to find the extent of authenticity of narrative text models. Based on the criteria of assessing the authentic material above, the researcher choose the book entitled "Once Upon a Time: Treasury of Fairy Tales" for many reason. First, the editors are native English speaking. Second, the text represent the communicative intention of the native speakers. Third, The text used in the context of english speaking countries. Fourth, The book use of language in real context. 


\section{Authenticity}

Employing authenticity in EFL classroom is an important element for both material designer and language teacher. Many researchers believe that authenticity is very significant, because it can brings the learners to the real world situations in terms of target language. Today, language learner has high expectations of authenticity-of target language texts, of facts about the target culture and, not least, of interaction used to obtain this information (Mishan, 2005, p. xi).

The terms of authenticity is not easy to define. According to Tatsuki (2006, p. 1) "authenticity is taken as being synonymous with genuineness, realness, truthfulness, validity, reliability, undisputed credibility, and legitimacy of materials or practices". Moreover, MacDonald, Badger, and Dasli (2006) state that if there is a correspondence between the texts used in the classroom and types of texts used outside the classroom then it is possible to call such texts authentic.

Mishan (2005, p. 18) discuss the criteria for assessing the authenticity of the text, in the context of language learning material design. They are: 1). Provenance and authorship of the text. This statement requires us to analyze who the authors are? Native or non-native speakers of the language; 2) Original communicative and sociocultural purpose of the text. It means that the text should represent the communicative intention of the native speakers; 3 ). Original context (e.g. its source, socio-cultural context) of the text. The text should be used in the context of english speaking countries. 4). Learning activity endangered by the text. The task sould be related to use of language in real context. 5). Learners' perceptions of and attitudes to the text and the activity pertaining to it. What views do the learners of the text have when reading the text? Do they feel it like their own language?

Therefore, this research aims to find out the authenticity of the text (English narrative) that used in Junior High School textbooks by doing comparative study of narrative text in JHS textbooks and narrative text that used by English native speakers or called authentic material.

\section{Narrative Text}

The main focus of this research is narrative text for it is the most frequently occured and widely used in language teaching. Anderson and Anderson (1997, p. 8) explain that a narrative is a text that tells a story and, in doing so, entertains the audience. Generally, the stories constructed by five generic structures they are orientation, complication, sequence of events, resolution and coda (Anderson \& Anderson, 1997). In orientation narrator introduces who is in the story, when the story is taking place, and where the action is happening. In complication, the narrator tells about something that will begin a chain of events. These events will affect one or more of the characters. Then, in the next step, sequence of events, the narrator tells how the characters react to the complication. In this step, the feelings of the character and what they do are included. In addition, the events can be told in chronological order (the order in which they happen) or with flashbacks. The audience is given the narrator's point of view. In resolution part, complication is sorted out or the problem is solved. Coda is an optional structure in a narrative. In this part, the narrator includes a coda if there is to be a moral or message to be learned from the story (Anderson \& Anderson, 1997) but most of the teacher simplified the generic structure into orientation, complication and resolution so that narrative text is easily understood by their students.

\section{Vladimir Propp's Theory of Narative}

Vladimir Propp (1895-1970) famous as a Russian formalist approach to narratology (the study of narrative structure). In 1928, Propp has conducted a research on hundreds of russian folktales. The important point based on his research are; First, functions of characters serve as stable, constant and independent of how and by whom it is fulfilled. It means that the most stable elements of the folktales is the functions of the characters. Second, the number of the functions known to the fairy tales is limited. It means that fairy tales has limited number of functions and it's become a principal unit in a storyline. 


\section{Types of The Characters}

Propp (1968) concluded that all the characters could be resolved into 8 broad character types in the 100 tales he analyzed: First, The Villain - struggles against the hero. Second, The dispatcher - character who makes the lack known and sends the hero off. Third, The helper - helps the hero in their quest. Fourth, The princess or prize - the hero deserves her throughout the story but is unable to marry her because of an unfair evil, usually because of the villain. The hero's journey is often ended when he marries the princess, thereby beating the villain. Fifth, Her father - give the task to the hero, identifies the false hero, marries the hero, often sought for during the narrative. Propp (1968) noted that functionally, the princess and the father cannot be clearly distinguished. Sixth, The donor - prepares the hero or gives the hero some magical object. Seventh, The hero or victim/seeker hero - reacts to the donor, weds the princess. Eight, False hero - takes credit for the hero's actions or tries to marry the princess.

\section{Functions}

Vladimir Propp also broke up fairy tales into sections. By using the sections, he was able to define the tale into series of sequences. Propp found that usually there is an initial situation, after which the tale usually takes the following 31 functions. Propp used this method to decipher Russian folklore and fairy tales.

The first seven narathemes/ functions introduce the initial story situation: who, where, when, how and why. 1). Absentation; 2). Interdiction; 3).Violation of Interdiction; 4). Reconaisance; 5). Delivery; 6).Trickery; 7). Complicity; 8).Villainy or Lack; 9).Mediation; 10). Beginning Counter-Action; 11). Departure;12). First Function of the Donor; 13). Hero's Reaction; 14).Receipt of a Magical Agent; 15). Guidance; 16).Struggle; 17).Branding; 18).Victory; 19).Liquidation; 20). Return: Hero returns; 21).Pursuit: Hero is pursued (pursuer tries to kill, eat, undermine the hero); 22). Rescue; 23).Unrecognized Arrival; 24). Unfounded Claims; 25). Difficult Task; 26).Solution: Task is resolved; 27). Recognition: Hero is recognized; 28). Exposure: False hero or villain is exposed; 29). Transfiguration; 30). Punishment: Villain is punished; 31). Wedding: Hero marries and ascends the throne (is rewarded/promoted). (Propp, 1968, pp. 12-42)

The Vladimir Propp's theory of narrative is chosen in this research for many reason. First, there can be no doubt that Propp's analysis is a landmark in the study of folklore. Second, Propp's Morphology may also have important implication for studies and learning process. Third, because researcher believe that the most stable element of the tale is functions, this theory is suitable to analyze the narrative text models that used in Junior High School to value the extent of the authenticity of the text.

\section{METHODOLOGY}

To provide some responses for the research question, the researcher used a qualitative research. The type of this research is a document or content analysis. The data of this research are four narratif text models that used in Junior High School Textbooks and the authentic version of them.

The procedures of data analysis were ilustrated as; First, the researcher collected the narrative text model from Junior High School textboks and narrative text model in English speaking country. Second, the researcher apply the related theory to analyzed the data. The researcher used narrative theories of Vladimir Propp (including characters and functions) to analyze the data. Next, Comparing the finding from chosen data by using theories. In this step, the researcher compare the finding of the characters and functions on the narrative text model used in Junior High School textbooks with the finding of the analysis on the narrative text from the authentic materials. Next, Obtaining and interpretting several findings on the research that answer statement of the problems. Fifth, Carrying out the research finding into discussion, analyzing them and interpret the result. Fifth, making conclussion from findings and discussion.

In order to verify the trustworthiness of the finding of this research, the researcher used triangulation. 


\section{FINDINGS}

The Application of Vladimir Propp's Theory of Narrative on Narrative text models used in Junior High School textbooks.

\section{Propp's Characters}

\section{a. Characters of Little Red Riding Hood}

1) Characters of Little Red Riding Hood in Scaffolding VIII textbook.

Little Red Riding Hood story in Scaffolding VIII textbook only has three of eight Propp characters, they are the villain, princess, and the hero. Bellow are the explanation:

The villain in this text is the wolf that ate the girls and her grandmother. It can be seen in the sentence "A wolf wanted to eat her but was afraid to do so in a public". The villain here is not struggles against the hero but the villain wants to eat the girl. Because the story is out of the kingdom setting, the possition of princess is acted by the girl.

The hero is a character who reacts to the donor and weds the princess. But in this story the hero reacts to help the girl to save her life. In this story, the hero is the hunter who help the girl by killing the wolf.

2) Characters of Little Red Riding Hood in Once Upon a Time: Treasury of Fairy Tales storybook.

The story of Little Red Riding Hood in Once Upon a Time: Treasury of Fairy Tales storybook has three of eight Propps characters they are villain, princess and th hero.

The villain of this story is a wolf who tries to eat the little girl. The wolf said "All the better to EAT you with" then the wolf chased after her.

The princess of the story is a little girl, and the hero of te story is the woodcutter who helped the little girl from the attack of the wolf that wants to eat her. There are two people which are not accomodated by the characters discovered by Vladimir Propp's theory. They are Little Red Riding Hood's mother and Grandmother.

b. Characters of Snow White

1) Characters of Snow White in Contextual Teaching and Learning VIII textbook

The story of Snow White in Contextual Teaching and Learning VIII textbook has five of eight Propps' characters they are the villain, dispatcher, magical helper, princess, and the hero.

The villain in this story is the Queen or Snow White's step mother, she was jelaous of Snow White's beauty and she wanted her to die. The dispatcher also acted by the Queen, she turned into witch and gave Snow White a poisoned apple. Unfortunately, Snow White did not realize it.

The princess is the Snow White, The magical helper in this story is acted by the prince charming "Fortunately, in the end, Prince Charming revived her with a kiss". It is called magic because the prince revive princess from a long time sleep only by a kiss. The hero in this story also the prince charming because he save her life and marry her.

2) Characters of Snow White in Contextual Teaching Learning IX textbook

The story of Snow White in Contextual Teaching Learning IX textbook is a new version, it has three of eight Propps characters they are villain, princess and hero.

The villain in this story are her uncle and aunt, it can be seen in the second paragraph.

'One day she heard her Uncle and Aunt talking about leaving Snow White in the castle because they both wanted to go to America and they didn't have enough money to take Snow White'.

Her uncle and aunt want to leave Snow White in the castle while they go to America. 
The princess is Snow White herself and the hero are the seven dwarves. It can be seen in the sentence 'one of the dwarfs, said, "If you wish, you may live here with us". the dwarfves save her life by let her stay with them.

3) Characters of the Snow White in Once Upon a Time: Treasury of Fairy Tales storybook

The characters of Snow White story in this storybook has six of eight Propps characters they are villain, dispatcher, magical helper, princess, her father, and the hero.

Villain of the story is the Queen (Snow White's step mother). It can be seen in the story when She ordered him (the huntsman) to take into the forest and kill her (Snow White) at once. She also gave the poisonous apple to make Snow White sleep for a very long time.

The dispatcher of the story is also the wicked queen. She tries to kill Snow White three times. She disguise herself as a seamstress, peddler and the last as the farmer to trick Snow White and unfortunately she did not realize it.

The princess of the story is Snow White. While, Her father is the King. The hero of the story is the seven dwarves and the prince. The seven dwarves helped her when ...The evil queen pulled the laces so tight that Snow White could not breathe, and she fell to the floor, bound in the lovely gown..., then when Snow White fell to the ground after the comb from the wicked quenn touched her head. The Prince helped the princess when she was slept for a long time by bring her to the kingdom and fortunately, the bit of poisoned apple fell from Snow White's mouth. The Snow white saved and the prince marry her.

\section{c. Characters of Cinderella}

1) Characters of the Cinderella in English in focus IX textbook

The story of Cinderella in English in Focus IX textbook has four of eight characters, they are villain, magical helper, princess and the hero.

The villain are her step mother and sisters because They treated cinderella badly and ask her to do all the house work. Magical helper is the fairy God mother, the fairy God mother came and helped Cinderella to go to the ball to join the dance party at the ball.

Princess in this story is Cinderella, and the hero is the prince. The prince finally maried her and it means helped Cinderella to set free from her step mother and sisters who treated her badly.

2) Characters of the Cinderella in Once Upon a Time: Treasury of Fairy Tales storybook.

The characters of cinderella story in Once Upon a Time: Treasury of Fairy Tales storybook has five of eight Propps character. They are villain, dispatcher, magical helper, princess, and hero.

Villain of the story is cinderella step mother and sisters. Now, this dreadful stepmother expected her kind and beautiful stepdaughter to do all of the dirtiest household chores. Her stepsisters also treat her badly "Cinderella!" her stepsisters would chant. "Clean the cinders, Cinderella!"

The dispatcher of the story also the Cinderellas stepmother. When the prince ask cinderella to try the slipper, her stepmother always hinders him and said "Dirty Cinderella?" laughed the wicked stepmother. "certainly she is not the girl you love!"

The magical helper in this case is the fairy god mother who helped cinderella to go to the ball.

"I am here to help you. I have watched while your family has mistreated you, and I have come to help bring you the good fortune you deserve. Tonight is the night of the royal ball, is it not? Would you like to go?"

The princess of the story is Cinderella. And the hero is the prince who felt in love with her and save her life from the wicked stepmother. The Prince had found his love at last. Cinderella and the prince were soon married. They lived happily ever after. 


\section{Propp's Functions}

i. Functions of Little Red Riding Hood

1) Functions of Little Red Riding Hood in Scaffolding VIII textbook

1). Absentation; a family member puts themself in danger by leaving home environment. In this story, the function ilustrated as The girl walked through the woods to deliver food to her grandmother. 2). Reconaisance: has the aim of finding out something precious objects. In this function, the wolf tries to find information about where the girl wants to go. 3). Delivery: The villain receives information about his victim. She naively told him where she was going. The sentence before ilustrated the function of delivery. 4). Trickery: the villain attempts to deceive the victim to take possession of victim or victim's belongings ( trickery; villain disguised, tries to win confidence of victim).

In the meantime, he went to the grandmother's house and gained entry by pretending to be the girl. He ate the grandmother and waited for the girl. He disguised as the grandmother.

The sentence before is the ilustration of the function of the text. 5). Villainy; villain causes harm/injury to family member. In this case, the wolf ate the grandmother and the girl too. The vilainy led the next function. 6). Hero's reaction; hero reacts to actions of future donor. However a hunter came to rescue and cut the wolf open. That sentence suitable as the ilustration of the Propp's function of Hero's reaction. 7). Solution: the task is resolved. The ilustration of the function in the text stated as Little Red Riding hood and her mother emerged unharmed. They filled the wolf's body with heavy stones, which killed him.

2. Functions of Little Red Riding Hood in Once Upon a Time: Treasury of Fairy Tales storybook.

1). Absentation; In this text, the function ilustrated as One day her mother said, "Grandmother is sick. Please take her this basket of goodies. Be sure that you stay on path". Little Red Riding Hood mother asked her to go to Grandmother house. 2). Interdiction; this function ilustrated by the words Be sure that you stay on the path. 3). Violation of Interdiction; on the way to grandmother's house, Little Red Riding Hood forget her mother's warning, She wandereded off the path and into the fragnant woods. 4). Reconaisance: has the aim of finding out something precious objects, the wolf asked the girl where she wants to go. "Where are you going, little girl?" Asked the wolf. 5). Delivery: The villain receives information about his victim. "I am going to visit my grandmother, who lives in the house with the red door," answered the girl. The little girl naively told him where she was going, She did not know anything about hungry wolves, so she was not afraid. The sentence before ilustrated the function of delivery. 6). Trickery: the wolf tries to trick the little girl to eat her. the wolf disguising himself as grandmother.

Then the wolf dressed in one of Grandmother's night gowns. He put on a sleeping bonnet and slipped into Grandmother's comfortable bed to wait for Little Red Riding Hood..

The sentence before is the ilustration of the function of the text. 7). Villainy; villain causes harm/injury to family member. In this case, the wolf tries to eat the girl. The vilainy led the next function. 8). First function of the donor; Little Red Riding Hood let out a scream and ran from the room. The wolf leaped from the bed and chased after her. when the little girl attacked by the wolf, it becomes the donor itself 9). Hero's reaction; hero reacts to actions of future donor. He reached for the wolf and grabbed him by the tail. Then the woodcutter carried the wolf into the forest. That sentence suitable as the ilustration of the Propp's function of Hero's reaction and 10). Exposure; the villain is exposed as the wolf carried into the forest by the woodcutter. 11). Solution: the task is resolved. The ilustration of the function in the text stated as:

Grandmother gave Little Red Riding Hood a great big hug as the woodcutter came out of the woods.....The Woodcutter, Little Red Riding Hood and Grandmother enjoy the basket of goodies as they sat and told stories for the rest of the day. 


\section{b. Functions of Snow White}

1) Snow White in Contextual Teaching Learning VIII textbook

1). Absentation; the function ilustrated as Snow White knew about the evil plan. She escaped into forest. 2). Trickery; in this section, the villain disguise herself as a witch and give Snow White a poisonous apple. 3). Villainy; the wicked queen wanted to kill Snow White as stated in the sentence She was very jealous of her beauty. So she wanted her to die. 4). First function of the donor; Snow White was put into sleep for years and this became the donor of the princess for the next function. 5). Receipt of magical agent; the prince revived Snow White by a kiss. 6). Wedding; They lived together happily ever after. The sentence before can be ilustrate as the function of wedding.

2) Snow White in Contextual Teaching Learning IX textbook

1). Absentation; the absentation function in this text ilustrated as The next morning she ran away from home when her Aunt and Uncle were having breakfast. She ran away into the woods. 2). Return; the hero returns, this function marked by the sentence Meanwhile, the seven dwarfs were coming home from work. They went inside. 3). Unrecognized Arival; the seven dwarves found Snow White sleeping in their house. There they found Snow White sleeping. Then Snow White woke up. She saw the dwarves. The dwarves said, "what is your name?" Snow White said, "My name is Snow white.". 4). Transfiguration; seven dwarves let Snow White live in their house and they lived hapily ever after.

3) Snow White in Once Upon a Time: Treasury of Fairy Tales storybook.

The functions that can be detected in this text are 1). Absentation; She (the Queen) ordered the him (huntsman) to take Snow White to the forest and kill her at once. That ilustration appropriate with the definition of absentation of Propp's functions. A family member leaving the home environtment took by the huntsman. 2). Interdiction; according to Propp, the interdiction is the addressed to the hero, but in this story this function is addressed to the huntsman. He ordered to take the Snow White to the forest and kill her. But he didn't do that. The next function is 3). Violation of interdiction;

...when she looked at him with her gentle eyes, full of trust, the huntsman could not bring himself to carry out the queens's order. He left Snow White in the forest and warned her never to return to the castle.

The ilustration before appropriate with the function of violation of interdiction. 4). Reconaisance; the queen tries to find Snow White through the magical mirror. She often in disguise to find Snow White.

Next, 5). Villainy; the queen always try to kill Snow White because of her jealousy. 6). Mediation; this function is marked by the failure of the villain in killing Snow White. She always helped by the seven dwarves. The functions of Villainy and Mediation happened twice in continue. The seven dwarves have been helped Snow White twice, they have to make a decission to save Snow White. This action is known as 7). Begining Counteraction; The function is ilustrated in the text as:

The dwarves rejoiced, but they were worried that the queen would try to harm Snow White again. They made Snow White promise not to open the door for anyone but themselves.

8). First function of the donor; finally after Snow White slept for along time caused by the poisonous apple and the seven dwarves cannot helped her again, this is the perfect moment of the appearance of the hero. So it called the first function of the donor. 9). Hero's Reaction; ilustrated by "I will take her to my castle until she awakens. Then if she is willing, I will ask her to be my wife." This action led the next function. 10). Return; the Prince (hero) back to the castle with Snow White. 11). Punishment; the queen crept into the forest. 12) 
Transfiguration; ilustrated in the text as There were dances and feasts, and Snow White was happier than she had ever been. 13). Wedding; the prince and Snow White finally married and ruled the kingdom with kindness and wisdom and live hapily ever after. The result of this research seemingly had a similar result from previous research by Puspitasari (2014).

\section{c. Functions of Cinderella}

1) Cinderella in English in Focus IX textbook

The Propp's functions of Cinderella in English in Focus IX textbook are; 1). Interdiction; the ilustration of the interdiction in this story when Cinderella had to do all the housework and when there was a party, the stepsister would not let her go. 2). Vilainy; were ilustrated as They treated her badly. 3). First Function of the donor; this function ilustrated in the text as ...her stepsisters would not let her go. Cinderella was sad. The stepsisters went to the ball without her. 4) Guidance; when the fairy godmother came and helped her to the ball is the suitable condition of the function. 5). Wedding; The ilustration of the function of wedding based on Vladimir Propp were The prince fell in love with her and then married her.

2) Cinderella in Once Upon a Time: Treasury of Fairy Tales storybook.

The next presentation are the Propp's functions analysis of the Cinderella story in Once Upon a Time: Treasury of Fairy Tales storybook. The functions are 1). Interdiction; in this function Cinderella turned from family member to a worker. In the text were ilustrated as:

Now, this dreadful stepmother expected her kind and beautiful stepdaughter to do all the household chores. The girl peeled the potatoes and scrubbed the floors. She washed the dishes and split the firewood.

These bad treatment to Cinderella also led to the next function. 2). Vilainy; the cinderella stepmother and sisters treat her badly. this function stated clearly in the text as:

Cinderella!" her stepsisters would chant. "Clean the cinders, Cinderella!"..."Cinderella", her stepmother would demand "clean the fireplace until it shines! I don't want to see a single cinder left".

3). First donor function; Cinderella is punished and banned from the dance party at the ball by her stepmother. This functions will led to the next function. 4). Receipt of a magical agent; this function ilustrated as Fairy godmother appear and dressed Cinderella. 5). Guidance; The fairy godmother help and guides Cinderella to the ball by giving magic spell. 6) Hero is Pursued; Cinderella searces for the prince to dance. 7).Difficult task; is proposed to hero. The prince tries to find the owner of the glass slipper, the girl he loves. He goes around the kingdom searching the girl whoever it fits and he will marry. 8). Solution; Cinderella freed from her locked up and have a chance to try on the slipper. In this case the task is resolved. 9) Recognation; the hero and the princess recognized by the slippers, because the slipper fits Cinderella. 10) Wedding; in the last story, finally Cinderella and the prince were soon married. They lived happily ever after. The sentence before is the appropriate ilustration of the wedding function.

\section{B. The Authenticity of Narrative text models used in Junior High School textbooks resemble the narrative text used in English speaking country.}

Finished describing the result of Propps characters and functions analysis of narrative text models in those four textbooks and Once Upon a Time: Treasury of Fairy Tales storybook, below, this research continued doing comparative analysis. This analysis was taken to provide answer of the second question, the authenticity of narrative text models used in Junior High School Textbooks resemble narrative text in Once Upon a Time: Treasury of Fairy Tales storybook. 


\section{Little Red Riding Hood}

Table 4.1 Little Red Riding Hood Characters Comparing checklist

\begin{tabular}{|l|l|l|l|}
\hline No & \multicolumn{1}{|c|}{$\begin{array}{c}\text { Characters } \\
\text { (1) }\end{array}$} & \multicolumn{1}{|c|}{$\begin{array}{c}\text { Scaffolding VIII } \\
\text { Textbook }\end{array}$} & \multicolumn{1}{c|}{$\begin{array}{c}\text { Once Upon a Time } \\
\text { Storybook }\end{array}$} \\
\hline $\mathbf{1}$ & The Villain & The wolf & The Wolf \\
\hline $\mathbf{2}$ & The Dispatcher & & \\
\hline $\mathbf{3}$ & The Magical Helper & & The little girl \\
\hline $\mathbf{4}$ & The Princess & The girl & \\
\hline $\mathbf{5}$ & Her Father & & The woodcuter \\
\hline $\mathbf{6}$ & The Donor & The Hunter & \\
\hline $\mathbf{7}$ & The Hero & & \\
\hline $\mathbf{8}$ & The False Hero & Table 4.2 Little Red Riding Hood Propp's Functions comparison checklist
\end{tabular}

\begin{tabular}{|c|c|c|c|}
\hline No & Functions & Scaffolding VIII & $\begin{array}{c}\text { Once Upon a } \\
\text { Time }\end{array}$ \\
\hline (1) & (2) & (3) & (4) \\
\hline 1 & Absentation & $\mathrm{V}$ & V \\
\hline 2 & Interdiction & & V \\
\hline 3 & Violation of Interdiction & & V \\
\hline 4 & Reconaisance & V & $\mathrm{V}$ \\
\hline 5 & Delivery & $\mathrm{V}$ & V \\
\hline 6 & Trickery & V & V \\
\hline 7 & Complicity & & \\
\hline 8 & Villainy or Lack & V & V \\
\hline 9 & Mediation & & \\
\hline 10 & Beginning Counter-action & & \\
\hline 11 & Departure & & \\
\hline 12 & First function of the donor & & \\
\hline 13 & Hero’s Reaction & $\mathrm{V}$ & $\mathrm{V}$ \\
\hline 14 & Receipt a Magical Agent & & \\
\hline 15 & Guidance & & \\
\hline 16 & Struggle & & \\
\hline 17 & Branding & & \\
\hline 18 & Victory & & \\
\hline 19 & Liquidation & & \\
\hline 20 & Return & & \\
\hline 21 & Pursuit & & \\
\hline 22 & Resque & & \\
\hline 23 & Unrecognized Arrival & & \\
\hline 24 & Unfounded Claims & & \\
\hline 25 & Difficult Task & & \\
\hline 26 & Solution & V & $\mathrm{V}$ \\
\hline 27 & Recognition & & \\
\hline 28 & Exposure & & \\
\hline 29 & Transfiguration & & \\
\hline 30 & Punishment & & \\
\hline 31 & Wedding & & \\
\hline \multicolumn{2}{|c|}{ SUM } & 7 & 9 \\
\hline
\end{tabular}

2. Snow White (Contextual Teaching and Learning VIII textbook)

Table 4.3 Snow White Characters Comparing checklist 


\begin{tabular}{|l|l|l|l|} 
No & \multicolumn{1}{|c}{ Characters } & \multicolumn{1}{c|}{$\begin{array}{c}\text { CTL VIII } \\
\text { Textbook }\end{array}$} & \multicolumn{1}{c|}{$\begin{array}{c}\text { Once Upon a Time } \\
\text { Storybook }\end{array}$} \\
\hline $\mathbf{( 1 )}$ & \multicolumn{1}{|c|}{$(\mathbf{2})$} & \multicolumn{1}{c|}{$(\mathbf{3})$} \\
\hline $\mathbf{1}$ & The Villain & The queen & The queen \\
\hline $\mathbf{2}$ & The Dispatcher & The queen & The queen \\
\hline $\mathbf{3}$ & The Magical Helper & Prince Charming & \\
\hline $\mathbf{4}$ & The Princess & Snow White & Snow White \\
\hline $\mathbf{5}$ & Her Father & & The King \\
\hline $\mathbf{6}$ & The Donor & & Snow White \\
\hline $\mathbf{7}$ & The Hero & Prince Charming & Seven Dwarves and Prince \\
\hline $\mathbf{8}$ & The False Hero & & \\
\hline & & & \\
\hline
\end{tabular}

Table 4.4 Snow White in CTL VIII Propp's Functions Comparison Checklist.

\begin{tabular}{|c|c|c|c|}
\hline No & Functions & CTL VIII & $\begin{array}{c}\text { Once Upon a } \\
\text { Time }\end{array}$ \\
\hline (1) & (2) & (3) & (4) \\
\hline 1 & Absentation & $\mathrm{V}$ & $\mathrm{V}$ \\
\hline 2 & Interdiction & & $\mathrm{V}$ \\
\hline 3 & Violation of Interdiction & & $\mathrm{V}$ \\
\hline 4 & Reconaisance & & V \\
\hline 5 & Delivery & & \\
\hline 6 & Trickery & V & \\
\hline 7 & Complicity & & \\
\hline 8 & Villainy or Lack & $\mathrm{V}$ & V \\
\hline 9 & Mediation & & $\mathrm{V}$ \\
\hline 10 & Beginning Counter-action & & V \\
\hline 11 & Departure & & \\
\hline 12 & First function of the donor & V & V \\
\hline 13 & Hero's Reaction & & V \\
\hline 14 & Receipt a Magical Agent & V & \\
\hline 15 & Guidance & & \\
\hline 16 & Struggle & & \\
\hline 17 & Branding & & \\
\hline 18 & Victory & & \\
\hline 19 & Liquidation & & \\
\hline 20 & Return & & $\mathrm{V}$ \\
\hline 21 & Pursuit & & \\
\hline 22 & Resque & & \\
\hline 23 & Unrecognized Arrival & & \\
\hline 24 & Unfounded Claims & & \\
\hline 25 & Difficult Task & & \\
\hline 26 & Solution & & \\
\hline 27 & Recognition & & \\
\hline 28 & Exposure & & \\
\hline 29 & Transfiguration & & V \\
\hline 30 & Punishment & & $\mathrm{V}$ \\
\hline 31 & Wedding & $\mathrm{V}$ & $\mathrm{V}$ \\
\hline \multicolumn{2}{|r|}{ SUM } & 6 & 13 \\
\hline
\end{tabular}

3. Snow White (Contextual Teaching and Learning IX textbook)

Table 4.5 Snow White Characters Comparing checklist

\begin{tabular}{|c|c|c|c|}
\hline No & Characters & $\begin{array}{l}\text { CTL IX } \\
\text { Textbook }\end{array}$ & $\begin{array}{c}\text { Once Upon a Time } \\
\text { Storybook }\end{array}$ \\
\hline (1) & (2) & (3) & (4) \\
\hline 1 & The Villain & Uncle and Aunt & The queen \\
\hline 2 & The Dispatcher & & The queen \\
\hline
\end{tabular}




\begin{tabular}{|l|l|l|l|}
\hline $\mathbf{3}$ & The Magical Helper & & \\
\hline $\mathbf{4}$ & The Princess & Snow White & Snow White \\
\hline $\mathbf{5}$ & Her Father & & The King \\
\hline $\mathbf{6}$ & The Donor & & Snow White \\
\hline $\mathbf{7}$ & The Hero & Seven Dwarves & Seven Dwarves and Prince \\
\hline $\mathbf{8}$ & The False Hero & & \\
\hline
\end{tabular}

Table 4.6 Snow White CTL IX Propp's Functions comparison checklist

\begin{tabular}{|c|c|c|c|}
\hline No & Functions & CTL IX & $\begin{array}{c}\text { Once Upon a } \\
\text { Time }\end{array}$ \\
\hline (1) & (2) & (3) & (4) \\
\hline 1 & Absentation & $\mathrm{V}$ & $\mathrm{V}$ \\
\hline 2 & Interdiction & & V \\
\hline 3 & Violation of Interdiction & & $\mathrm{V}$ \\
\hline 4 & Reconaisance & & $\mathrm{V}$ \\
\hline 5 & Delivery & & \\
\hline 6 & Trickery & & \\
\hline 7 & Complicity & & \\
\hline 8 & Villainy or Lack & & V \\
\hline 9 & Mediation & & V \\
\hline 10 & Beginning Counter-action & & V \\
\hline 11 & Departure & & \\
\hline 12 & First function of the donor & & V \\
\hline 13 & Hero's Reaction & & V \\
\hline 14 & Receipt a Magical Agent & & \\
\hline 15 & Guidance & & \\
\hline 16 & Struggle & & \\
\hline 17 & Branding & & \\
\hline 18 & Victory & & \\
\hline 19 & Liquidation & & \\
\hline 20 & Return & V & V \\
\hline 21 & Pursuit & & \\
\hline 22 & Resque & & \\
\hline 23 & Unrecognized Arrival & $\mathrm{V}$ & \\
\hline 24 & Unfounded Claims & & \\
\hline 25 & Difficult Task & & \\
\hline 26 & Solution & & \\
\hline 27 & Recognition & & \\
\hline 28 & Exposure & & V \\
\hline 29 & Transfiguration & V & V \\
\hline 30 & Punishment & & \\
\hline 31 & Wedding & & $\mathrm{V}$ \\
\hline & SUM & 4 & 13 \\
\hline
\end{tabular}

From the table it can be seen that the text in CTL IX only has four of thirtyone functions, meanwhile the text in the book that researcher chose as comparison has thirteen of thirtyone Propp's functions.

4. Cinderella

Table 4.7 Cinderella Characters Comparing checklist

\begin{tabular}{|l|l|l|l|}
\hline No & \multicolumn{1}{|c|}{$\begin{array}{c}\text { Characters } \\
\text { (1) }\end{array}$} & \multicolumn{1}{|c|}{$\begin{array}{c}\text { English in Focus } \\
\text { Textbook }\end{array}$} & \multicolumn{1}{c|}{$\begin{array}{c}\text { Once Upon a Time } \\
\text { Storybook }\end{array}$} \\
\hline $\mathbf{1}$ & The Villain & \multicolumn{1}{c|}{$(\mathbf{3 )})$} \\
\hline $\mathbf{2}$ & The Dispatcher & Stepmother & Stepmother \\
\hline $\mathbf{3}$ & The Magical Helper & Fairy god mother & Stepmother \\
\hline
\end{tabular}




\begin{tabular}{|l|l|l|l|}
\hline $\mathbf{4}$ & The Princess & Cinderella & Cinderella \\
\hline $\mathbf{5}$ & Her Father & & \\
\hline $\mathbf{6}$ & The Donor & Prince & \\
\hline $\mathbf{7}$ & The Hero & & Prince \\
\hline $\mathbf{8}$ & The False Hero & \\
\hline
\end{tabular}

Table 4.8 Cinderella functions comparison checklist

\begin{tabular}{|c|c|c|c|}
\hline No & Functions & English in Focus & $\begin{array}{c}\text { Once Upon a } \\
\text { Time }\end{array}$ \\
\hline (1) & (2) & (3) & (4) \\
\hline 1 & Absentation & & \\
\hline 2 & Interdiction & V & V \\
\hline 3 & Violation of Interdiction & & \\
\hline 4 & Reconaisance & & \\
\hline 5 & Delivery & & \\
\hline 6 & Trickery & & \\
\hline 7 & Complicity & & \\
\hline 8 & Villainy or Lack & $\mathrm{V}$ & $\mathrm{V}$ \\
\hline 9 & Mediation & & \\
\hline 10 & Beginning Counter-action & & \\
\hline 11 & Departure & & \\
\hline 12 & First function of the donor & V & V \\
\hline 13 & Hero’s Reaction & & \\
\hline 14 & Receipt a Magical Agent & & $\mathrm{V}$ \\
\hline 15 & Guidance & $\mathrm{V}$ & $\mathrm{V}$ \\
\hline 16 & Struggle & & \\
\hline 17 & Branding & & \\
\hline 18 & Victory & & \\
\hline 19 & Liquidation & & \\
\hline 20 & Return & & \\
\hline 21 & Pursuit & & V \\
\hline 22 & Resque & & \\
\hline 23 & Unrecognized Arrival & & \\
\hline 24 & Unfounded Claims & & \\
\hline 25 & Difficult Task & & V \\
\hline 26 & Solution & & V \\
\hline 27 & Recognition & & $\mathrm{V}$ \\
\hline 28 & Exposure & & \\
\hline 29 & Transfiguration & & \\
\hline 30 & Punishment & & \\
\hline 31 & Wedding & $\mathrm{V}$ & $\mathrm{V}$ \\
\hline & SUM & 5 & 10 \\
\hline
\end{tabular}

\section{Conclusion}

From the result of the analysis, it can be conclude that First, Vladimir Propp's theory is generally applicable to the narrative text models used in Junior High School textbooks. However, not all characters in the text are accomodated by the theory and the texts didn't fulfill all the functions. Second, all of the text are belong to not authentic text. Three of them are the simplification of the authentic texts and the other is created text. This was caused by the students level of knowledge, curiculum regulations and cultural context.

Sugestion, for EFL teacher, it is highly recommended to use an authentic texts in teaching English. The non authentic text is suitable, but authentic text should be introduced. For textbooks author, it is recomended that providing simplified authentic text is better than creating new text. But if they want to create narrative text, it is hardly recommended to use narrative theory, for instance Vladimir Propp's theory. For further researcher, it is suggested to analyze Indonesian 
folktales using Propp's theory. It is also interesting to have a research on the use of authentic texts in teaching English.

\section{References}

Ali, Na'ima Mosa. (2010). An Evaluation of the Reading Texts \& Exercises in SB \& WB of English for Palestine - Grade 9. (Master Degree), Islamic University of Gaza, Palestina.

Anderson, Mark, \& Anderson, Kathryn. (1997). Text types in English (Vol. 2): Macmillan Education AU.

Ary, Donald, Jacobs, Lucy Cheser, \& Sorensen, Chris. (2010). Introduction to Research in Education (8th ed.). Wadsworth, USA: Cengage Learning.

Azri, Rashid Hamed Al, \& Al-Rashdi, Majid Hilal. (2014). Effect Of Using Authentic Materials In Teaching INTERNATIONAL JOURNAL OF SCIENTIFIC \& TECHNOLOGY RESEARCH, 3(10), 249-254.

Bouchard, Nancy. (2002). A narrative approach to moral experience using dramatic play and writing. Journal of Moral Education, 31(4), 407-422.

Breen, Michael P. (1985). Authenticity in the Language Classroom*. Applied linguistics, 6(1), 60-70.

Brown, H. Douglas. (2001). Teaching by principles : an interactive approach to language pedagogy (2nd ed.). White Plains, NY: Longman.

Butt, David, Fahey, Rhonda, Spinks, S, \& Yallop, C. (2000). Using Functional Grammar: An Explorer's Guide. National Centre for English Language Teaching and Research. Macquarie University, Sydney.

Creswell, John W. (2008). Educational Research (3rd ed.). New Jersey: Pearson Education.

Derewianka, Beverly. (1990). Exploring How Texts Work: Primary English Teaching Association Sydney.

Fraenkel, Jack R., Wallen, Norman E., \& Hyun, Helen H. (2012). How to Design and Evaluate Research in Education (8th ed.). New York: Mc Graw-Hill.

Gorski, Kelly.). The Lunacy of the Fictional Narrative. Retrieved January 21, 2015, from http://www.artdealersandgalleries.com.php53-4.dfw1-1.websitetestlink.com/articles-onart.php?The+Lunacy+of +the+Fictional+Narrative $\& I D=4320$

Harmer, Jeremy. (1991). The practice of English language teaching. London/New York.

Hyland, Ken. (2003). Second language writing: Cambridge University Press.

Jordan, Robert R. (1997). English for academic purposes: A guide and resource book for teachers: Cambridge University Press.

Kusuma, Lyla Anggerwina. (2013). The Authenticity of Conversation Transcripts Used in Junior High School BSE Textbooks (Conversation Analysis Approach). Universitas Negeri Surabaya, Surabaya.

Larimer, Ruth E, \& Schleicher, Leigh. (1999). New Ways in Using Authentic Materials in the Classroom. New Ways in TESOL Series II: Innovative Classroom Techniques: ERIC.

Lee, Winnie Yuk-chun. (1995). Authenticity revisited: Text authenticity and learner authenticity. ELT journal, 49(4), 323-328.

MacDonald, Malcolm N, Badger, Richard, \& Dasli, Maria. (2006). Authenticity, Culture and Language Learning. Language and Intercultural Communication, 6(3\&4), 250.

McDonough, Jo, Shaw, Christopher, \& Masuhara, Hitomi. (2013). Materials and Methods in ELT: A Teacher's Guide (Third ed.). Oxford: Wiley-Blackwell.

Mikesofa, Lenka. (2006). The Usage of Fairy Tales in English Lesson and Their Influence on Children's Social Development

Univerzita Pardubice.

Mills, Melinda, Bunt, Gerhard G. van de, \& Bruijn, Jeanne de. (2006). Comparative Research : Persistent Problems and Promising Solutions. International Sociology, 21(5), 619-631. 
Mishan, Freda. (2005). Designing authenticity into language learning materials: Intellect Books. Morrow, Keith. (1977). Authentic texts in ESP. English for specific purposes, 13-17.

Nunan, David. (1989). Designing Tasks for the Communicative Classroom. United Kingdom: Cambridge University Press.

Nunan, David. (1999). Second Language Teaching and Learning. Boston: Heinle and Heinle.

Nuttall, C. (1996). Teaching Reading Skills in a foreign language. Oxford: Heinemann.

Propp, Vladimir Iakovlevich. (1968). Morphology of the Folktale (Vol. 9): University of Texas Press.

Richards, Jack C. (2001). Curriculum development in language teaching: Ernst Klett Sprachen.

Rogers, Carmen Villegas, \& Medley, Frank W. (1988). Language with a purpose: Using authentic materials in the foreign language classroom. Foreign Language Annals, 21(5), 467-478.

Rosyidah, A. (2012). Character Building Through English Teaching. Balai Diklat Keagamaan Surabaya, 4, 1-7.

Swales, John. (1990). Genre analysis: English in academic and research settings: Cambridge University Press.

Tatsuki, D. (2006). What is authenticity? The Language Teacher, 16 (5), 17-21. Retrieved October 1, 2006.

Tompkins, Gail E. (1994). Teaching writing: Balancing process and product: Macmillan College. Yimwilai, Supaporn. (2009). Using Narrative Texts to Teach Reading. มนุษยศาสตร์ ปริทรรศน์, 29(1).

Young, Tory. (2008). Studying English literature: a practical guide: Cambridge University Press. 